\title{
12 Inside the Great Outdoors
}

\section{A Complete and Unabridged Guide: With Travelogue, Bestiary, Judgement}

\author{
Line Henriksen
}

\section{DEDICATION}

This is a guide for those who have:

1. Secrets that eat them up from inside

2. Unrealistic expectations to the spacetime continuum

3. Unfinished business

4. A broken heart

If you have none of the above, this guide will provide them for you.

\section{FOREWORDS}

"Here! I'm in here!"

\section{INRODUCING YOU AND ME}

I know you think of space. You think of empty space a lot. This is understandable, of course. I don't judge. No, I don't write guides in order to judge people. I mean, if I did, where would I be work-wise, right? My guides on How to Travel with Umbrellas, A Vade Mecum to the Void and To Hell in a Handbasket never would have done as well as they did were I busy belittling my readers, now, would they? No no, call me old-fashioned, but I save my judgement for the right one.

So you think of space. You think of empty space a lot, and I watch you and don't judge, because you have Your Reasons, you have your longings for the Great Outdoors, you have your plans, you have your moods that stir the weather, that draw in large grey clouds like a blanket around the shoulders of the city. Your mood makes mist hiss in the alleyways and snow sprout in-between floorboards, and one day you find your coffee mug hovering. Not much, just enough to draw a perfectly round shadow, a small black hole underneath it. With two fingers on the handle, you carefully 


\section{Line Henriksen}

maneuver the mug back down. When next you look up, it has sunk halfway into the table. I don't think it's necessary for anyone to know more about you than this, and since words can never contain me, let's begin.

\section{BESTIARY}

You: Fictional body. A read body.

$M e$ : Beyond words. A reading cosmos. Weirdly realistic.

\section{CHAPTER 1}

\section{NEVER RECEIVED A CARD}

You're welcome, by the way. For all that I did, and all that I'm about to do. I don't expect gratitude. Words cannot contain my magnanimity anyway. Magnanimity. Now there's a word.

\section{CHAPTER 2}

\section{STEP ONE: A REPRESSED MEMORY}

"Here! In here!"

\section{CHAPTER 3 STEP TWO: AN ITCH}

Whenever you close a door, space presses in on you. It itches, like a woolly sweater, or that yellow dress you once loved but that is now too small, too snug, too old-fashioned.

\section{BESTIARY}

Yellow dress, possibly silk.

Long skirt, high sleeves.

Idiotically old-fashioned.

Dangerous when approached. Impossible to remove.

You pick at the sleeves, absentmindedly, until a thread comes undone, and you wind it around your finger-one time, two times, three times-and you have to tug at it to make it move.

Nothing.

You tug again, harder.

Nothing, nothing.

You tug again.

Something comes undone.

Something gives way.

Something's at the door. 
CHAPTER 4

STEP THREE: OPEN THE DOOR

There's nothing at the door. You linger a while and nothing changes. You don't see that, because you're a little dim. I say that lovingly.

CHAPTER 5

STEP FOUR: BEGIN AT ANY STEP YOU LIKE. THERE IS NO SPECIFIC ORDER TO THESE EVENTS

\section{CHAPTER 6}

\section{STEP FIVE: KNOCK KNOCK KNOCK}

You lock the bathroom door and sit on the toilet seat, lid down, legs up. You listen to the steady knock knock knock of nothing at the front door all night.

\section{CHAPTER 7}

\section{STEP SIX: THINKING OF YOU}

Space thinks of you. Empty space thinks of you a lot. I watch you both and don't judge, because you have Your Reasons, you have your longings for the Great Outdoors and the Vast Inside. You have your plans, you have your moods that stir the weather, that draw in nebulas like pearls around a lover's neck. You should talk more often. You should communicate better.

You don't even realize that there's another knocking, small and delicate. Coming from inside the bathroom. Coming from inside the toilet bowl.

\section{CHAPTER 8}

STEP SEVEN: REPEAT STEP ONE

"Here here!"

\section{CHAPTER 9}

\section{STEP EIGHT: SPIRITS}

Spirits communicate by knocking-once for yes, twice for no. This one is saying "maybe."

\section{CHAPTER 10}

\section{STEP NINE: FOLDINGS}

The city folds. Time to the right, space to the left, meet in the middle. Tug in the ends. 


\section{Line Henriksen}

\section{CHAPTER 11}

\section{STEP TEN: TAKE THE FLIPPER}

Feet down, breath held, lid up.

There's a tiny bird moving through the water in the toilet bowl.

"There's not much space!" it says. "Take my flipper!"

It's a penguin, you think, but you're wrong.

There's a live penguin in my loo! you think, but you're wrong.

I don't mean to keep pointing out your flaws, you just have so many.

\section{BESTIARY}

Great auk, not a penguin.

wonderful, incredibly beautiful

watches you with a curious expression.

A ghost.

\section{CHAPTER 12}

\section{STEP ELEVEN: FOLDINGS}

The kitchen folds. Pots to the left, kettle to the right, sink sinks. Ends like gossamer tentacles squirming from the flowerpots.

\section{CHAPTER 13}

\section{STEP TWELVE: A REPRESSED MEMORY}

You are flushed out, legs in the air, a swarm of water twirling around your kicking feet.

Gone.

\section{CHAPTER 14}

\section{STEP THIRTEEN: FOLDINGS}

The door folds. Right corner left; left corner center. Floor opening in the middle for a maelstrom the size of continents to peep through. The ends are here.

\section{BESTIARY}

The dead.

\section{CHAPTER 15 STEP FOURTEEN: INSIDE OUTDOORS}

You think of space. You think of empty space a lot, and the Great Auk watches you curiously and doesn't judge. It knows the Great Outdoors as well as the Vast Inside, because they're all the same thing, really, or so a philosopher Great Auk might say. Something dramatic, like: 
"It seeps."

or

"All of us are dead, flowing over the bridge."

or

"You should send more postcards. Writing opens the mind to the Great Outdoors."

That last one was me, I admit. Not the Great Auk.

\section{BESTIARY}

Text.

Empty spaces in between non-empty spaces.

A séance held by the dead calling the living.

\section{CHAPTER 16}

\section{STEP FIFTEEN: YOU HAVE ARRIVED}

The door unfolds. Right corner right; left corner left. Floor closing like the eyelid of a maelstrom the size of continents.

The kitchen unfolds. Pots back in the cupboards, kettle plugged in, sink pops back up. Gossamer tentacles withdraw from the flowerpots.

The city unfolds. The ends are undone.

You are where you want to be.

I wish you'd write more often. 
